\title{
Analysis of Business Development Strategy with Fuzzy SWOT Method (Case Study in the Potato Chips SMES Cluster)
}

\author{
Ainun Lady, Siti Asmaul Mustaniroh*, Retno Astuti \\ Department of Agro-industrial Technology, Faculty of Agricultural Technology, Universitas Brawijaya, Malang, Indonesia \\ *Corresponding author. Email: asmaul_m@ub.ac.id
}

\begin{abstract}
Potato chips small and medium enterprises (SMEs) in Batu City were formed into 2 clusters (micro and small scale) based on production capacity, sales turnover, number of labor, and length of production operation. SMEs "Agronas Gizi Food" and "Gajah" are representatives from these clusters which have good performance. The level of competition for the potato chips SMEs is increasing, thus encouraging the owners to develop strategies for expanding the market. The problems faced by the potato chips SMEs include the unstable supply of raw materials and the inconsistent quality of potato chips. The purpose of this study was to analyze alternative business development strategies in the potato chips SMEs cluster based on supply chain institutions and product quality using the Fuzzy SWOT method. The variables were measured based on supply chain institutions (i.e. farmers to distributors) and the quality of the production (i.e. color, size, crispness, and consistency of shape) with two potato chips SMEs as respondents. The results showed that the alternative strategy for supply chain institutional development in the potato chips SMEs cluster, in particularly is increasing the cooperative model partnership in the supply of raw materials. The alternative strategy to improve product process quality is standardization in the production process and product quality based on SNI.
\end{abstract}

Keywords: Cluster, Potato Chips, Quality, Strategy, Supply Chain

\section{INTRODUCTION}

Potatoes are one of the horticultural commodities with the highest productivity in Batu City. According to the Central Bureau of Statistics, in 2019, potato production reached 9.138 tons. High potato production became an opportunity for the potato-based production industry, specifically for potato chips product. Until 2021, there are 30 SMEs in Batu City that produce potato chips, from microscale to intermediate. Potato chips SMEs are classified based on production capacity indicator, operational duration, average monthly revenue, Halal certificate, and the number of labor. From these categories, the SMEs are grouped into 2 clusters. First, cluster $1^{\text {st }}$ is a small-sized business such as Ramadjaja, Gizifood, Rimbaku, and Istana. Second, cluster $2^{\text {nd }}$ is a micro-sized business such as Gajah, Santoso, Asli, Super, and Sri Rejeki.
To enhance the performance of the potato chips SMEs cluster, various development strategies are urgently needed enabling these SMEs to be more competitive. Many factors are important in business continuity, including supplier chain and quality control. Supplier chain control is critical due to its relation with the ingredients and quality, as well as precise delivery time. Furthermore, those aspects also affect the efficacy of the production process and the ability to fulfil the customers' needs [1]. To know the quality product matches the customers' demand, SMEs need to apply the quality control [2].

In development, there are many issues encountered, especially the supplier chain factor and quality control. Issues in the supplier chain include no standards on the supply quality, the fluctuated potato prices, and the unpredictable weather (or climate), which may affect the potato supplies. Issues in the quality control include simple tools and 
production processes, which hindering the SMEs to produce products that fit with the quality standards. Furthermore, agro-industrial competitiveness can be created and improved through quality control activity and production control. The evaluating and fixing the production activity, promotions, and information relay to the manufacturer are parts of the improvement activities [3]. Utilizing and fixing the quality product is more important in determining competitiveness [4].

Therefore, a comprehensive analysis is needed, starting from internal to external surroundings in SMEs. Internal and external surroundings analysis results can be used as an evaluation for SMEs and as the basis for designing their improvement. The analysis is widely carried out using Fuzzy SWOT. Fuzzy SWOT is applied in the same way as SWOT analysis however, there is some fuzzy logic applied to tackle fuzzy factors in an issue. The fuzzy SWOT method is used for analyzing problems in internal and external factor, as well as for determining alternative strategies to be applied in SMEs based on the issues identified. This study aimed to analyze alternative business development strategies in the potato chips SMEs cluster based on supply chain institutions and product quality using the Fuzzy SWOT method.

\section{MATERIALS AND METHODS}

The respondents of this study were Agronas Gizifood SME (cluster ${ }^{\text {st }}$ ) and Gajah SME (cluster $\left.2^{\text {nd }}\right)$. The variables used include internal and external variables (Table 1). The fuzzy SWOT method is superior to the SWOT method; however, it differs with 3 conditions in which Fuzzy SWOT's matrix includes optimistic, probable, and pessimistic values. The fuzzy SWOT method was only used to design alternatives improvement and not to apply those alternatives to the SMEs.

\subsection{Fuzzy SWOT}

There were several steps in the Fuzzy SWOT's analysis, as follows:

\subsubsection{Internal and External Analysis}

The objective of internal surroundings analysis was to identify internal factors (such as strengths/S and weaknesses/W). Utilizing the strength can be used as an advantage for competitiveness. The weakness had to be minimized and fixed to face the changes in the future. The objective of external surroundings analysis was to utilize the opportunities $(\mathrm{O})$ or anticipate the threats $(\mathrm{T})$ that affect SMEs' continuity. This step as carried out by analyzing the internal and external surroundings variables, as shown in Table 1.

Table 1. Internal and external variables

\begin{tabular}{|l|l|l|l|}
\hline Variables & Description & Variables & Description \\
\hline S1 & Short supply chain flow & W1 & $\begin{array}{l}\text { No standard on the potato supply } \\
\text { specifications }\end{array}$ \\
\hline S2 & Fair gain for the supplier chain & W2 & Potato buying with the contract system \\
\hline S3 & Good relation with the supplier & W3 & $\begin{array}{l}\text { Farmers or suppliers are also doubles as } \\
\text { the SMEs owner }\end{array}$ \\
\hline S4 & Punctual material availability & W4 & Diverse product quality standards \\
\hline S5 & $\begin{array}{l}\text { Varied potato for easier quality } \\
\text { control }\end{array}$ & W5 & $\begin{array}{l}\text { Machines and production process hinders } \\
\text { the quality control }\end{array}$ \\
\hline S6 & Standard SOPs & W6 & Limited R\&D functionality and facility \\
\hline Variables & Description & Variables & Description \\
\hline O1 & $\begin{array}{l}\text { SMEs is located near the supplier } \\
\text { T1 }\end{array}$ & $\begin{array}{l}\text { The uncertain climate influence o the } \\
\text { potato supplies }\end{array}$ \\
\hline O2 & $\begin{array}{l}\text { The tools improvement for easier } \\
\text { production }\end{array}$ & T2 & Fluctuated potato prices \\
\hline O3 & SMEs carry out product innovation & T3 & Increasing demand for potatoes \\
\hline
\end{tabular}

\subsubsection{Internal and external valuing}

The internal and external variables valuing were done by some expert respondents. By a linguistic scale ( $\mathrm{VL}$ to $\mathrm{VH}$ ), the expert respondents gave the values to the SMEs internal and external variables. The variable valuing scale can be seen in Table 2 [5]. 
Table 2. Variable rating scale

\begin{tabular}{|l|l|}
\hline Scale & Description \\
\hline VL & Very low variable influence \\
\hline L & Low variable influence \\
\hline ML & Moderate-Low variable influence \\
\hline M & Moderate variable influence \\
\hline MH & Moderate-high variable influence \\
\hline H & High variable influence \\
\hline VH & Very high variable influence \\
\hline
\end{tabular}

\subsubsection{Converting Variable Value to TFN}

Valuation results of internal and external variables were then converted into the Triangular Fuzzy Number (TFN) scale. The TFN showed the variable values in three conditions such as optimistic, probable, and pessimistic. The fuzzy SWOT's TFN value in this research was using a value scale from -4 to +6 . The weakest position for the weaknesses scale or threat was showed with a value of -4 and for the strongest position for the strengths scale or opportunity with a value of +6 . The value range for the TFN condition is as follows where pessimistic value $\leq$ probable $\leq$ optimistic. This stage was aimed to identify the three conditions (pessimistic, probable, and optimistic) in each internal and external variable. The scale obtained from TFN is illustrated in Figure 1.

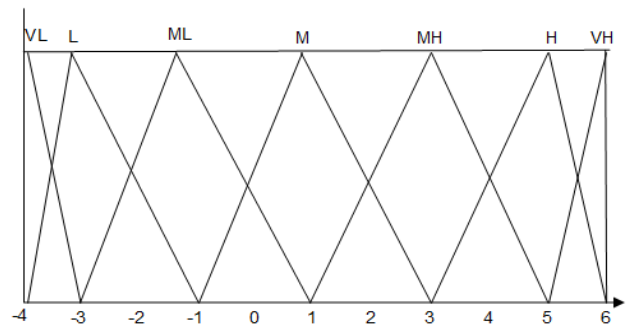

Figure 1 Fuzzy number linguistic scale [5]

\subsubsection{Determining Variable's Average Value}

The average variable value was obtained by adding values from every variable and dividing it by the number of respondents, as shown in Equation 1.

$$
\left(\mathrm{A}_{\mathrm{jk}} \mathrm{B}_{\mathrm{jk}} \mathrm{C}_{\mathrm{jk}}\right)=\frac{1}{\mathrm{~N}}\left(\sum_{\mathrm{i}=1}^{\mathrm{N}} \mathrm{Ajk}, \sum_{\mathrm{i}=1}^{\mathrm{N}} \mathrm{Bjk}, \sum_{\mathrm{i}=1}^{\mathrm{N}} \mathrm{Cjk}\right)
$$

Where:
$A_{j k}=$ smallest value for pessimistic condition

$\mathrm{B}_{\mathrm{jk}}=$ middle value for probable condition

$\mathrm{C}_{\mathrm{jk}}=$ middle value for optimistic condition

$\mathrm{N}=$ number of respondents

\subsubsection{Determining the Variable's Priority Scale}

The priority scale valuation was based on consideration of how important the impact from variables to the SMEs. Each internal and external variable is valued in a $1-100$ scale (Table 3 ). If the number of respondents is more than one then the average value is used.

Table 3. Priority Scale Fuzzy SWOT

\begin{tabular}{|l|l|}
\hline Scale & Description \\
\hline $1-10$ & Absolute unimportant \\
\hline $11-20$ & Very unimportant \\
\hline $21-30$ & Unimportant \\
\hline $31-40$ & Little unimportant \\
\hline $41-50$ & Normal \\
\hline $51-60$ & Important \\
\hline $61-70$ & A little important \\
\hline $71-80$ & More important \\
\hline $81-90$ & Very important \\
\hline $91-100$ & Absolute important \\
\hline
\end{tabular}

\subsubsection{Determining the Variable's Weight}

Weighting the variable was aimed to obtain the weight value from every respondent. The weight value was obtained by adding the total value of all internal and external variables. The weight total from all variables (internal and external) was 1 .

\subsubsection{FIF and FEF Values Calculation}

The average fuzzy value from every factor is based on the multiplication of every variable and the weight, as shown in Equation 2.

$$
A j=\sum_{k=1}^{n j} W_{j k} A_{j k}, B j=\sum_{k=1}^{n j} W_{j k} B_{j k}, C j=\sum_{k=1}^{n j} W_{j k} C_{j k}
$$

Where:
$\mathrm{Aj}=$ pessimistic condition variable value
$\mathrm{Bj}=$ probable condition variable value
$\mathrm{Cj}=$ optimistic condition variable value
$\mathrm{Nj}=$ number of variables
$\mathrm{Wjk}=$ each variable's weight value 


\subsubsection{FIF and FEF Total Calculation}

The internal factors (FIF) and external factors (FEF) total value was obtained by adding the value from each variable.

\subsubsection{Determining SMEs' Position in the Fuzzy SWOT Matrix}

Determining the product's position or SMEs was carry out based on the FIF and FEF total value. The fuzzy's triangle area is shown with coordinates' majority location, where each area was inputted into the fuzzy SWOT's matrix. X-axis coordinate is from FIF's total value, while Y-axis is from FEF's total value. Overall, three coordinates were obtained based on the three conditions i.e pessimistic $\left(\mathrm{X}_{1}, \mathrm{Y}_{1}\right)$, probable $\left(\mathrm{X}_{2}, \mathrm{Y}_{2}\right)$, and optimistic $\left(\mathrm{X}_{3}, \mathrm{Y}_{3}\right)$. Those coordinates formed a fuzzy SWOT triangle that signify the SME's position and most suitable improvement strategy within the SME's existing conditions.

The fuzzy SWOT matrix contained 4 quadrants: SO, WO, ST, and WT. Those four quadrants resulted in four combinations of improvement strategy alternatives. The fuzzy SWOT matrix difference was supported by three conditions: pessimistic, probable, and optimistic.

\subsubsection{Determining the Gap between the Variables}

The gap between FIF and FEF variables was calculated using Equation 3, below:

$$
d[F I F, F E F] \frac{(a 1+2 a 2+a 3)-(b 1+2 b 2+b 3)}{4}
$$

Where:
$\mathrm{d} \quad=$ gap between FIF and FEF values
a1 = FIF pessimistic variable value
a2 = FIF probable variable value
a3 = FIF optimistic variable value
b1 = FEF pessimistic variable value
b2 = FEF probable variable value
b3 = FEF optimistic variable value

The internal influence is much bigger compared to the external if the value of FIF-FEF $<0$. This indicates that the basic strategy to be done was by fixing the
product/SMEs's weakness and increasing the product/SMEs's strength, or vice versa.

\subsubsection{Strategy Adjustment}

The alternative strategy was formed based on the SWOT factors and reviewed based on the fuzzy SWOT calculation and the position in the matrix. Therefore, severak alternative strategies may be obtained from SO, WO, ST, and WT strategy combinations.

\section{RESULTS AND DISCUSSION}

\subsection{Valuing Internal and External Variable Analysis}

The results of internal and external variable values by the respondent were converted into the TFN values. Based on the TFN scale, it was found that the values from each variable in pessimistic, probable, and optimistic conditions. Table 4 shows the linguistic value from VL to $\mathrm{VH}$ provided by the respondents.

After valuing the internal and external variables, weighting was done by giving the value using a scale from 1 - 100. Average weight obtained from weight total on each variable divided by the number of respondents. Table 5 shows weight given by the respondent.

Table 4. Valuing internal and external variable

\begin{tabular}{|l|l|l|}
\hline $\begin{array}{c}\text { Internal } \\
\text { Variable }\end{array}$ & R1 (Agronas Gizifood) & R2 (Gajah) \\
\hline S1 & ML & VL \\
\hline S2 & MH & VH \\
\hline S3 & VH & H \\
\hline S4 & H & ML \\
\hline S5 & VH & H \\
\hline S6 & H & MH \\
\hline W1 & MH & L \\
\hline W2 & L & L \\
\hline W3 & L & VL \\
\hline W4 & M & VL \\
\hline W5 & VH & M \\
\hline W6 & ML & VL \\
\hline External & R1 (Agronas Gizifood ) & R2 (Gajah) \\
Variable & & \\
\hline O1 & H & VH \\
\hline O2 & MH & VL \\
\hline O3 & M & L \\
\hline T1 & VH & MH \\
\hline T2 & M & MH \\
\hline T3 & M & M \\
\hline & & \\
\hline
\end{tabular}


Table 5. Weighting internal and external variables

\begin{tabular}{|l|l|l|}
\hline $\begin{array}{l}\text { Internal } \\
\text { Variable }\end{array}$ & $\begin{array}{l}\text { R1 (Agronas } \\
\text { Gizifood) }\end{array}$ & R2 (Gajah) \\
\hline S1 & 40 & 90 \\
\hline S2 & 90 & 90 \\
\hline S3 & 100 & 100 \\
\hline S4 & 50 & 100 \\
\hline S5 & 100 & 100 \\
\hline S6 & 90 & 90 \\
\hline W1 & 60 & 50 \\
\hline W2 & 50 & 10 \\
\hline W3 & 30 & 10 \\
\hline W4 & 50 & 10 \\
\hline W5 & 90 & 80 \\
\hline W6 & 40 & 60 \\
\hline External & R1 (Agronas & R2 (Gajah) \\
Variable & Gizifood) & \\
\hline O1 & 80 & 100 \\
\hline O2 & 70 & 100 \\
\hline O3 & 60 & 100 \\
\hline T1 & 90 & 80 \\
\hline T2 & 50 & 80 \\
\hline T3 & 60 & 90 \\
\hline
\end{tabular}

Next was calculating the FIF and FEF values. FIF value as obtained from the average addition value between the average internal variable value multiplications (Ajk, Bjk, Cjk) for every condition with internal variable average weight $(\mathrm{Wjk})$. The same procedure was applied to FEF calculation (external variable). Based on the calculation, obtained the FIF and FEF values are shown in Table 6 for three conditions.

Table 6. FIF and FEF values

\begin{tabular}{|l|l|l|}
\hline Condition & FIF & FEF \\
\hline Pessimistic & 0.462 & 0.472 \\
\hline Probable & 1.924 & 2.028 \\
\hline Optimistic & 3.114 & 3.475 \\
\hline
\end{tabular}

\subsection{Fuzzy SWOT Matrix}

The fuzzy SWOT matrix was adapted based on the FIF and FEF calculation results. FIF values determined the $\mathrm{X}$-axis coordinates, while FEF values determined the Y-axis. Pessimistic condition was on the coordinate (0.462;0.472), the probable condition was on the coordinate $(1.924 ; 2.028)$ and the optimistic condition was on the coordinate $(3.114 ; 3.475)$. These three conditions were on the SO quadrant. This demonstrated that improvement alternative strategy is determined based on the strength and opportunity (SO quadrant). The fuzzy SWOT matrix for the potato chips SMEs can be seen in Figure 2.

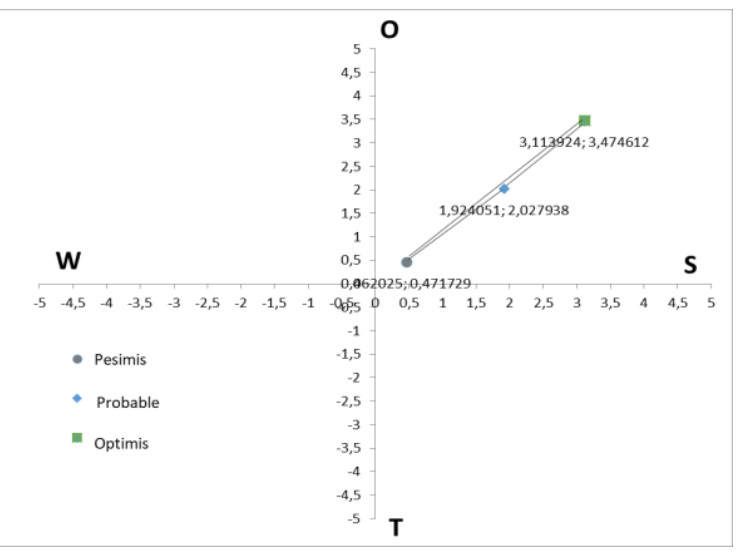

Figure 2 Fuzzy SWOT matrix

\subsection{Internal and external variable gap}

The calculation of the gap between FIF and FEF was needed to determine the most influential factor, either the internal or the external factors. FIF and FEF gap value calculation was calculated using Equation (3), obtaining the gap value between FIF and FEF of 0.144. If the FIF - FEF was < 1, then the internal factor was more influential than the external factor. Therefore, the results of this study indicated that the internal factor ws more influential towards the potato chips SMEs cluster development rather than the external factor. This result was in agreement with previous study reported by Nurcahyono et al. [6].

\subsection{Strategy Adjustment}

The fuzzy SWOT matrix showed the strategy alternative for improving SME potato chips was based on the first quadrant or SO strategy. SO strategy is to utilize all the opportunities and optimize the strengths of the company [7]. SO strategy is the best strategy as imposes the company to utilize the opportunities all around. The most appropriate strategy is the strategy that is development-oriented which the condition is profitable for the company [8]. Several alternative strategies potential to be implemented in the potato chip SMEs, include (1) technology implementation in the production process for increasing the product's quality, (2) product innovation by utilizing the 
availability of raw materials, (3) improvement in the raw material purchasing system with a good cooperative relationship between suppliers and producers, and (4) adjustment in the raw material handling.

\subsubsection{SO strategy adjustment: Technology implementation for improving product's quality}

The utilization of technology in the production process is critical for the potato chips SMEs. For quality improvement, the SMEs can evaluate the external factor, such as determining the value needed by the customer and product value that can be enhanced by benchmarking with the competitor. In that condition, the SMEs need to integrate the technology, external knowledge, and internal skills for adapting to the market condition [9]. Some methods can be used on improving product quality, such as the introduction of the product or service, the improvement of the materials and components, the simplicity of use, the improvement of the technical specification, etc [9]. An example of the use of technology for potato chip producers is a chopper machine designed to cut the potato chips to make a uniform shape and size. Consistency in the shape and size of potato chips is one of the consumer's requirements [10].

Besides for made a consistent size and shape of potato chips, a semi-automatic slicer can be used to decrease the material's preparation time, thus reducing the processing time. By applying the slicer, the result of market sales increased up to $77-80 \%$. This was possible due to an improvement in the appearance of potato chips include a consistent size, shape and quality [11].

\subsubsection{SO Strategy adjustment: Product innovation by utilizing the availability of raw materials}

The innovation of potato chips is needed to face an increasing market competitiveness and product diversification. The potato chips SMEs innovation is not only for the competitor of other potato chips, but also the other typical snack from Batu City (such as apple chips, snake fruit chips, and beverages). The SMEs cannot dominate the market only based on a variation consumer needs or rapid technological development at a long period just with one product variant. Therefore, the SMEs need to utilize external knowledge, internal skills, and integrated technology for facing and solving innovation problems [9].

In conducting product development, there are important aspects to be considered, specifically the availability of raw materials. The new product produced must be manufacturable, where the product has the convenience of being continuously produced [12]. The availability of raw material for potato chips is an opportunity for producers to carry out product development. Various approaches may be applied to achieve the innovative product of SME, such as improving an attribute of a new product, developing the consistency of product quality level, and improving the model and size of products [13].

\subsubsection{SO strategy adjustment: Improvement of the raw material purchasing system with a good cooperative relationship between suppliers and producers}

The material availability is related to the supply chain management of SME. The short supply chain supports the SMEs in controlling and improving material procurement. Developing the supply management of the SMEs is one of the strategies that can be used to increase competitiveness. It is because the supply chain is related to how big the SMEs have already achieved the effectiveness and efficiency [14]. Low quality of the raw materials, , can result in significant issues, especially in the food processing industry. The raw material purchasing strategy is classified into two main categories, include spot market and forward purchasing mechanism-contract. The spot market is flexible, practical, and does not require market analysis. However, the producers cannot choose raw materials at lower prices and there might be various uncertainties in the price sector and continuity of supply. While, in the forward purchasing mechanism contract, producers can communicate the need for raw materials and prices in the form of an agreement [6]. The SMEs apply the Just-in-time method on the material procurement where the SMEs bought the potatoes right before the production process. This procurement method allows the SMEs to reduce the idle activities, inventory, and work-in-process, as well as to eliminate unqualified suppliers [15].

\subsubsection{SO strategy adjustment: Adjustment of the raw material handling}

Various factors cause the inventory loss, such as respiration of the potatoes, germination, evaporation, potato disesase, physical properties change, chemistry 
ingredients, and extreme temperature. These factors are occurred because of the inventory condition [16]. Therefore, the appropriate inventory control is important. The increase of capital and inventory cost is incurred when the material stock is increased. If the material stock is reduced it can cause stock out. The cost of procuring an emergency stock is more expensive. Besides, no inventory control can hamper the production process and may lead to unsatisfied customers [17]. The material handling system on the company is a compulsory activity in an industry [14]. The total material handling cost is up to $30-75 \%$ of the total production cost. The material handling system efficiency can reduce company operational systems by as much as $15-30 \%$ [18]. Some approaches can also be used to increase the production process, specifically using proper material handling tools. A proper material handling tools aimed to improve the efficiency material flows, to utilize the facilities and to enhance the productivity [18]. The duration of storage and drying time of potatoes affects the quality of potato chips. Potato chips produced from potatoes previously stored for 1 day and dried at $50^{\circ}$ for 20 hours were the most preferred quality potato chips by the panelists [19].

\section{CONCLUSION}

An increase competition in the potato chips SMEs in Batu City encouraged the manufacturer to improve their performance. Various issues in improving the SMEs include: no standards quality is available for the potato supply, the fluctuated potato price, uncertain weather or climate, as well as the conventional machinery and technology. Such problems hinder the potato chips SMEs to produce the products with high quality standards. The findings in this study showed that, based on the internal and external analysis, the potato chips SMEs cluster are located in the SO quadrant. An alternative strategy that can be applied include (1) technology implementation in the production process for increasing the product's quality, (2) product innovation by utilizing the availability of raw materials, (3) improvement of the raw material purchasing system with a good cooperative relationship between suppliers and producers, and (4) adjustment of the raw material handling.

\section{REFERENCES}

[1] Alyas., M, Rakib, Strategi pengembangan usaha mikro, kecil, dan menengah dalam penguatan ekonomi kerakyatan (Studi kasus pada usaha Roti
Maros di Kabupaten Maros), Sosiohumaniora vol. 19, no. 2, 2017, pp. 114-120 [In Indonesian]

[2] D. Sonalia, dan M. Hubeis., Pengendalian mutu pada proses produksi di tiga usaha kecil menengah tahu Kabupaten Bogor, Jurnal Manajemen dan Organisasi, 2013, Vol. 4, No.2, 112-127 [In Indonesian]

[3] S.S. Kamble, R.D. Raut, Evaluating the factors considered for procurement of raw material in the food supply chain, International Journal of Productivity and Quality Management, vol. 26, no. 2, 2019, pp. 34-45. DOI: https://doi.org/10.1504/IJPQM.2019.097765

[4] Edward, Level of education, business experience and small and medium enterprise performance in the Accra Metropolis of Ghana, International Journal of Multidisciplinary and Current Research, vol. 5, 2017, pp. 1460-1466.

[5] S. Amin, R. Jafar, G. Zhang, Supplier selection and order allocation based on fuzzy SWOT analysis and fuzzy linear programming, International Journal Expert Systems with Applications, vol. 38, no. 1, 2011, pp. 334-342. DOI: https://doi.org/10.1016/j.eswa.2010.06.071

[6] N. Nurcahyono, W. Segoro, M.V. Bakara, Strategi pemasaran produk vsat kuband pada layanan internet dengan pendekatan analisa five porters dan fuzzy SWOT, IncomTech: Jurnal Telekomunikasi dan Komputer, vol. 4, no. 2 , 2013, pp. 173-192. DOI https://dx.doi.org/10.22441/incomtech.v4i2.1130 [In Indonesian]

[7] Muharto, Pariwisata Berkelanjutan: Kombinasi Strategi dan Paradigma Pembangunan Berkelanjutan, Deepublish, Yogyakarta, Indonesia, 2020 [In Indonesian]

[8] M. Djalil, Sulaeman, Strategi pengembangan usaha keripik ubi kayu pada industri pundi mas di kota Palu, e-J Agrotekbis, vol. 3, no. 3, 2015, pp. 390-401 [In Indonesian]

[9] H. Lee, S. Cha, H. Park, The effect of technologyexploration on product innovation: an analysis based on Korean manufacturing SMEs, International Journal of Quality Innovation, vol. 2, no. 1, 2016, pp. 1-15. DOI: https://doi.org/10.1186/s40887-016-0009-y

[10] V. Wadagafi, B. Kallihal, S. Dadanwale, M.C. Coukimath, et al., Automatic potato chips making machine, International Journal of Science and 
Research, vol. 78, no. 96, 2015 pp. 114-119.

[11] C. Anam, R. Uchyani, E. Widiyanti, Peningkatan daya saing keripik melalui perajang slice kentang dan desain kemasan di Sumberejo, Ngablak, Magelang, Journal of Community Empowering and Services, vol. 4, no. 1, 2020, pp. 22-29. DOI: https://doi.org/10.20961/prima.v4i1.38110 [In Indonesian]

[12] S. Taslim, Z. Zainuri., Pengembangan Produk Unggulan Desa, Kementerian Desa PDT dan Transmigrasi, Jakarta, Indonesia, 2019 [In Indonesian]

[13] T. Suhaeni., Pengaruh strategi inovasi terhadap keunggulan bersaing di industri kreatif (studi kasus UMKM bidang kerajinan tangan di kota Bandung), Jurnal Riset Bisnis dan Investasi, vol. 4, no. 1, 2018, pp. 57-74. DOI: https://doi.org/10.35313/jrbi.v4i1.992 Indonesian]

[14] A. Nugraha, S. Sukardi, A. Rifin, Efficiency of raw material inventories in improving supply chain performance of CV. Fiva Food, Indonesian Journal of Business and Entrepreneurship, vol. 1, no. 1,2016 , PP. 23-32. DOI: https://doi.org/10.17358/ijbe.2.1.23

[15] E.B.J. Janson, I.N. Nurcaya, Penerapan just in time untuk efisiensi biaya persediaan, E-Jurnal Manajemen Unud, vol. 8, no. 3, 2019, pp. 17551783 [In Indonesian]

[16] M.C. Alamar, R.Tosetti, S. Landahl, A. Bermejo, L.A. Terry, Assuring potato tuber quality during storage : a future perspective, Frontiers in plant science, vol. 8, 2017, pp. 1-6. DOI: https://doi.org/10.3389/fpls.2017.02034

[17] R. Vikaliana, Y. Sofian, N. Solihati, D.B. Adji, S.S. Maulia, Manajemen Persediaan, CV Media Sains Indonesia, Bandung, 2020 [In Indonesian]

[18] S. Dixit, T. Raj, A hybrid MADM approach for the evaluation of different material handling issues in flexible manufacturing systems, MDPI: Administrative Sciences, vol. 8, no. 69, 2018, pp. 1-19.

DOI: https://doi.org/10.3390/admsci8040069

[19] A. Asgar, K. Asih, S. Asep, T. Henna, Pengaruh lama penyimpanan, suhu, dan lama pengeringan kentang terhadap kualitas keripik kentang putih, Jurnal Biologi, vol. 10, no.2, 2010, pp 217-226 [In Indonesian] 